\title{
The Reform Strategy of the Local Government in Albania
}

\section{Doct. Arben Hysi}

University “Ismail Qemali” Vlore, Business Department

Doi:10.5901/ajis.2014.v3n3p541

Email: hysiarben@yahoo.com

\section{Abstract}

"In Albania, the local 's government operation and organization has historically been a responsibility and achieved by the will and physiognomy of the political class that had driven the social life. This process has been influenced even by the social characteristics, economic level, reflecting the impact of external political environment of the times in which is done the construction of local government as well as reform. Despite the government's project and efforts in Vlore, to make an administrative territorial division according to the model of Western countries France, until the year 92 that remained as the only attempt for a democratic process in the implementation of the local self-government. The political changes after the $90 \mathrm{~s}$ brought for the first time the local government organization according to the western concepts and practices as a result of the external political environment changes as well as the necessity of adaption the state of social and economic conditions in the Albanian society. Today the local government is organized and operates under the legislation of the Albanian Republic and "European Card of local autonomy", but the weakness shown during work as well as the social and economically changes, necessitate its reform. The practices followed in the developed countries and those former communist, are an aid to be taken in consideration in compliance with the conditions of our country. This study aims to bring debate in the way that the Local Government must be reformed and specifically what would like citizens according to a poll conducted in District of Gjirokaster ".

Keywords: Strategy, Government, Local, Administration, Reform . 